\title{
IMPLEMENTASI LEAN THINKING PADA PERUSAHAAN JASA BONGKAR - MUAT
}

\author{
Cut Rifafitri Hanifah \\ Program Manajemen Operasi, Sekolah Tinggi Manajemen PPM \\ Cut.rifa.fitri@gmail.com \\ Rizky Indra Aditya \\ Program Manajemen Operasi, Sekolah Tinggi Manajemen PPM \\ Radityaindra4@gmail.com \\ Andi Ilham Said \\ Program Manajemen Operasi, Sekolah Tinggi Manajemen PPM \\ AIS@ppm-manajemen.ac.id
}

\begin{abstract}
ABSTRAK
Penelitian ini bertujuan untuk menghasilkan rancangan strategi untuk peningkatan kinerja operasi pada perusahaan jasa bongkar - muat dan mengiplementasikan metode lean thinking pada perusahaan. Penelitian ini menggunakan metode kuantitatif dan kualitatif dimana teknik pengambilan sampel menggunakan metode cluster random sampling yang dikombinasikan dengan teknik probability sampling serta menggunakan wawancara untuk kategori atau level manajerial. Hasil dari riset ini ditemukan bahwa perusahaan menginginkan peningkatan kinerja operasi sebanyak 3 BCH (Box Crane Hours) di tahun 2020. Tetapi kinerja operasi perusahaan sekarang tidak bisa mencapai target tersebut, karena terdapat beberapa temuan masalah yang terjadi, seperti banyaknya idle di beberapa aktivitas. Untuk itu alternatif solusi dan strategi yang diberikan adalah strategi CRM (Consumer Relationship Management), allocation truck, dan split area. Dalam penelitian ini menggunakan Analis is Hirarki Proses (AHP) utuk mencari urutan alternative solusi atau strategi terbaik. Terdapat rangkaian rantai pas ok yang panjang dalam bisnis jasa bongkar - muat dan cukup banyak entitas yang terlibat sekitar 7 entitas, dimulai dari pemilik barang, penyedia ekspedisi dan lain-lain. Dalam penelitian ini hanya berfokus pada entitas penyedia jasa bongkar - muat container dan khusus di Dermaga Serbaguna Nusantara (DSN). Berdasarkan analisis terhadap kinerja operasi terdapat beberapa akar penyebab masalah yang terjadi di perusahaan, dengan begitu hasil temuan yang disarakan adalah Allocation truck, Split Area dan Customer Relationship Management. Perusahaan bisa memanfaatkan hasil temuan ini untuk mengetahui gambaran yang lebih obyektif mengenai operasi bisnis yang dilakukan selama ini dan bisa mencapai target kinerja 3 tahun ke depan.
\end{abstract}

Kata Kunci:

Jasa Bongkar-muat, Performance, Supply Chain, Lean Thinking, Continuous Improvement dan AHP.

\begin{abstract}
This study aims to generate a draft strategy for improving the performance of operations on service companies loading and unloading and implementing methods of lean thinking on the company. This research uses quantitative and qualitative methods where sampling technique using cluster random sampling method combined with probability sampling technique and using interview for category or managerial level. The results of this research found that the company wanted to increase operating performance by 3 BCH (Box Crane Hours) in 2020. But the performance of the company's operations now cannot reach the target, because there are several findings of the problems that occur, such as the number of idle in some activities. For that alternative solutions and strategies provided are CRM (Consumer Relationship Management), allocation truck, and sp lit area. In this study using Hierarchical Analysis Process (AHP) to find the sequence of alternative solutions or the best strategy. There is a long chain of supply chains in the business of loading and unloading services and quite a number of entities involved around 7 entities, ranging from goods owners, expedition providers and others. In this study only focuses on the service provider of loading and unloading container and special at Docks of Versatile Nusantara (DSN). Based on the analysis of the operational performance there are several root causes of problems that occur in the company, thus the findings are Allocation truck, Split Area and Customer Relationship Management. Companies can take advantage of these findings to find a more objective picture of the business operations undertaken so far and can achieve the next 3 years performance targets.
\end{abstract}

Keyword:

Stevedoring Service, Performance, Supply Chain, Lean Thinking, Continuous Improvement dan AHP 


\section{PENDAHULUAN}

Perkembangan dunia usaha saat ini terjadi semakin pesat. Hal ini diakibatkan dari semakin bertambahnya perusahaan barang dan perusahaan jasa. Banyaknya perusahaan baru yang muncul dan sejenis, mengakibatkan semakin banyak pilihan yang ditawarkan kepada konsumen. Keadaan tersebut menimbulkan persaingan di antara perusahaan untuk mendapatkan konsumen. Dengan kondisi yang seperti ini, maka perusahaan dalam operasionalnya termasuk ke dalam pendistribusian barang harus secara efektif dan efesien, sehingga perusahaan dapat mempertahankan kelangsungan hidupnya untuk berkembang.

Alur distribusi yang efisien menjadi kunci bagi perusahaan manufaktur dalam melakukan delivery produknya ke tangan konsumen. Terlebih untuk perusahaan fast moving consumer goods (FMCG), di mana barang-barang yang diproduksi merupakan barang kebutuhan sehari-hari bagi konsumen. Distribusi produk melibatkan banyak pihak, sehingga integrasi dari setiap pihak yang terlibat menjadi hal penting agar produk yang dikirimkan dapat diterima di tangan konsumen dengan baik. Hal tersebut sesuai dengan konsep supplychain, di mana tiap entitas dituntut untuk berperan dengan optimal agar efisiensi yang diinginkan dapat tercapai.

Indonesia adalah negara kepulauan yang artinya perlu biaya yang besar untuk melakukan delivery produk dari pusat hingga ke daerah pelosok di pulau yang berbeda. Pengiriman barang antar pulau dapat ditempuh melalui dua alternatif, yaitu melalui jalur udara dan melalui jalur laut. Jalur udara merupakan jalur pengiriman yang dianggap banyak orang dan para ahli sebagai jalur yang paling cepat. Hal ini juga cocok dengan kondisi geografis Indonesia. Namun tidak dapat dipungkiri bahwa jalur distribusi yang menggunakan jalur udara akan memakan biaya yang lebih besar. Untuk itu distribusi menggunakan jalur laut masih menjadi primadona di Indonesia bahkan di berbagai belahan dunia. Konsekuensi yang dihadapi adalah pengiriman produk biasanya dilakukan dalam jumlah yang besar.

Jumlah perusahaan pelayaran angkutan laut di Indonesia meningkat dari 483 perusahaan di tahun 2003 menjadi 688 perusahaan di tahun 2007 (Sudiyanto, 2008). Dominasinya perusahaan pelayaran berada di DKI Jakarta yang erat kaitannya dengan pusat kegiatan bisnis yang menggunakan pelayaran 
angkutan laut untuk jalur domestik maupun ekspor-impor melalui pelabuhan Tanjung Priok.

Data di atas menunjukkan tren meningkat dalam pertumbuhan perusahaan angkutan laut.

Distribusi barang melalui jalur laut yang sampai saat ini masih sangat dibutuhkan, menuntut setiap pelaku dalam industri ini untuk berperan secara optimal. Terlebih pada era pemerintahan Presiden Jokowi, sektor maritim menjadi fokus agar efisiensi distribusi dapat tercapai sehingga dapat meningkatkan perekonomian nasional. Tuntutan kinerja optimal harus dilakukan oleh seluruh pihak terkait seperti Pemerintah sebagai pembuat regulasi, pihak pelayaran sebagai penyedia alat transportasi untuk keperluan distribusi, juga pihak pengelola pelabuhan.

Berdasarkan Inpres no 4 tahun 1985 ditetapkan bahwa adanya pemisahaan usaha bongkar - muat dengan perusahaan pelayaran. Hal ini memunculkan banyak peluang bagi pengusaha untuk membuka usaha bongkar muat karena proses bongkar - muat kapal laut tidak akan berhenti selama kapal masih ada. Pengertian Perusahaan Bongkar - Muat berdasarkan Keputusan Menteri Perhubungan No. KM 14 Tahun 2002 adalah perusahaan berbadan hukum Indonesia yang khusus didirikan untuk menyelenggarakan dan mengusahakan kegiatan bongkar - muat kapal, dengan kata lain yaitu penyedia jasa bongkar muat dengan menggunakan Tenaga Kerja Bongkar Muat (TKBM) dan peralatan bongkar - muat (Trivitas, 2015). Perusahaan jasa bongkar - muat merupakan salah satu entitas dalam supply chain atau pihak yang berperan dalam distribusi produk. Perusahaan jasa bongkar - muat dituntut memiliki kinerja yang optimal dalam menjalankan operasi bisnisnya. Ada perusahaan yang langsung mengelola terminal Dermaga tidak bergantung dengan PT. Pelabuhan Indonesia II dalam operasionalnya. Dengan adanya hal itu, perusahaan dapat memberikan informasi kepastian kepada pelanggan tentang kapan kapal akan bersandar di dermaga secara akurat dan cepat, kemudian dengan adanya peralatan yang memadai maka akan mempercepat produktifitas, hal itu bisa menjadi keunggulan bagi perusahaan.

Sejak tahun 2006 sampai dengan 2015, total bongkar - muat barang dalam negeri atau domestik yang ada di pelabuhan Tanjung Priok menunjukkan tren meningkat. Hal ini menunjukkan bahwa permintaan customer (customer needs) kian lama semakin meningkat. Untuk itu keandalan dari perusahaan jasa 
bongkar - muat juga harus ditingkatkan agar customer tidak berpindah ke perusahaan bongkar - muat lain di Tanjung Priok Jakarta.

Dalam meningkatkan kinerja atau performa dalam menjalankan bisnis penyedia jasa layanan bongkar - muat container dan pengelolaan terminal, dalam penelitian ini menggunakan metode Lean Thinking dengan salah satu tool yang digunakan adalah Value Stream. Dengan menggunakan tool ini, perusahaan akan mengetahui proses mana yang memiliki value added, non - value added, dan non-value added but necessary dalam proses bisnisnya. Setelah diketahui, langkah selanjutnya adalah menyusun strategi perbaikan atau improvement bagi proses yang kurang memberikan dampak signifikan bagi operasi bisnis.

Perusahaan ingin meningkatkan target kinerja operasi naik $3 \mathrm{BCH}$ (Box Crane Hours) untuk 3 tahun ke depan. Kemudian penelitian ini juga menggunakan pendekatan Kaizen (Continuous Improvement) untuk meningkatkan kualitas dan menjaga kepuasan pelanggan terhadap layanan jasa yang diberikan. Untuk itu, penting bagi perusahan dalam memetakan proses bisnisnya dan melakukan identifikasi pada setiap tahapan proses. Hal ini akan membantu dalam proses perbaikan kinerja dengan target yang sudah ditentukan oleh pihak manajemen.

BCH atau Box Crane Hour adalah ukuran yang digunakan perusahaan bongkar muat untuk menunjukkan performa kinerjanya. Angka $\mathrm{BCH}$ menunjukkan banyaknya container yang dapat ditangani dalam aktivitas bongkar - muat dalam satu jam aktivitas. Semakin besar angka $\mathrm{BCH}$, maka semakin baik keandalan suatu perusahaan bongkar - muat. Angka $\mathrm{BCH}$ ini yang menjadi modal bagi perusahaan bongkar - muat untuk mendapatkan customer.

Komponen dari $\mathrm{BCH}$ dipengaruhi dari banyak hal seperti kemampuan alat, ketersediaan lapangan atau container yard (CY), kondisi cuaca pada saat melakukan aktivitas bongkar - muat, kondisi dermaga, keandalan dari operator, dan lain sebagainya. Seluruh faktor ini memiliki hubungan yang saling terkait dalam proses aktivitas bongkarmuat. Sehingga dalam melakukan perbaikan atau improvement tidak dapat melihat dari salah satu faktor atau satu sudut pandang saja.

Bila melihat rangkaian supply chain yang panjang, maka entitas yang terlibat dalam bisnis ini cukup banyak. Banyak pihak yang 
sebenarnya mempengaruhi indikator kinerja perusahaan bongkar - muat, walaupun pengaruh yang diberikan tidak langsung. Pihakpihak luar tersebut seperti Dinas Perhubungan dan Dinas Pengerjaan Umum yang bertanggung jawab atas kondisi infrastruktur distribusi barang. Sebagai contoh, bila jalanan yang dilalui truk-truk ekspedisi mengalami kerusakan, maka pengiriman barang ke pelabuhan akan terhambat. Terhambatnya pengiriman barang bisa juga disebabkan oleh kapal yang terlambat datang untuk bersandar di pelabuhan. Ini bisa berakibat pada waktu menunggu container menjadilebih lama.

Dalam suatu rantai pasok pada industri bongkar - muat container, setidaknya terdapat 7 pihak yang terlibat. Mulai dari pemilik barang, penyedia ekspedisi, perusahaan shipping line, agency, pelabuhan, pengelola terminal, dan penyedia bongkar - muat. Dari pihak-pihak tersebut, semua bertanggung jawab untuk tersampaikannya barang dengan baik. Untuk itu seluruh pihak harus memiliki kinerja yang baik. Dari entitas-entitas yang terlibat, penelitian ini berfokus pada entitas penyedia jasa bongkar muat container.

\section{TINJAUAN TEORI}

\section{Lean Six Sigma}

Lean Six Sigma merupakan gabungan dari dua metode yaitu metode Lean Thinking dan metode Six Sigma. Lean Thinking biasa digunakan untuk menciptakan efisiensi sebuah proses. Efisiensi dapat diperoleh dengan cara menghilangkan sebuah aktivitas atau menggabungkan beberapa aktivitas. Sedangkan metode Six Sigma adalah sebuah metode yang digunakan untuk meminimalkan variasi. Variasi ini bisa berupa produk yang dihasilkan ataupun waktu yang diperlukan dalam melakukan aktivitas. Sehingga metode Lean Six Sigma ini bertujuan untuk menciptakan aktivitas yang efisien dari sebuah proses dan meminimumkan variasi agar kualitas yang baik dapat tercapai.

Efisiensi yang dicapai dengan metode Lean Six Sigma bertujuan untuk mereduksi cost ataupun meningkatkan kinerja. Dengan demikian, keuntungan yang diperoleh dapat bertambah. Prinsip dari Lean Six Sigma ini adalah kemampuan perusahaan dalam melakukan identifikasi aktivitas mana yang merupakan aktivitas kritis dimana aktivitas tersebut berdampak pada kualitas layanan yang diberikan (George, 2002). 
Tujuan dari Lean Six Sigma adalah

untuk menentukan aktivitas mana yang menyebabkan proses berjalan dalam waktu yang lama. Aktivitas ini selain berdampak pada kualitas layanan, juga berdampak pada cost, sumber daya, dan lead time. Dengan mengadaptasi Lean Six Sigma, diharapkan sebuah proses bisnis dapat menghilangkan aktivitas-aktivitas yang tidak memberikan nilai tambah bagi proses operasi. Bila aktivitas tidak dapat dihilangkan, setidaknya aktivitas tersebut dapat dikurangi waktu prosesnya, sehingga waktu yang diperlukan untuk melakukan seluruh aktivitas dapat dipersingkat dan tidak membutuhkan waktu yang lama.

\section{Value Stream Mapping}

Salah satu alat yang digunakan dalam menerapkan Lean Six Sigma adalah Value Stream Mapping. Value Stream Mapping menjadi salah satu hal penting dalam Lean Six Sigma karena dengan menggunakan alat ini, dapat didefinisakan aktivitas dalam suatu proses. Pendefinisian ini juga termasuk dalam memetakan sebuah proses dari awal hingga akhir. Bila dalam tahap ini terjadi kesalahan, maka tahapan selanjutnya tidak akan berarti Untuk itu dalam menggunakan Value Stream
Mapping dibutuhkan ketelitian dan kecermatan dalam mengamati setiap aktivitas.

Menurut Myerson (2012), Value Stream Mapping adalah penggambaran aktivitas dari sebuah proses secara utuh mulai dari awal sampai akhir (end to end). Proses tersebut baik digunakan dalam perusahaan manufaktur maupun perusahaan jasa. Produk harus mampu digambarkan dengan sangat jelas sejak masih berupa bahan baku sampai dengan ke tangan konsumen. Proses menggambarkan atau memetakan aktivitas-aktivitas yang terlibat dalam suatu proses, selain disebut dengan Value Stream Mapping juga banyak yang menyebutkan dengan istilah Business Process Reengineering (BPR).

Keuntungan menggunakan Value Stream Mapping adalah melihat hubungan antara aktivitas, alur material, dan alur informasi mana yang menyebabkan lead time. Dengan demikian dapat diketahui aktivitas mana yang memberikan added value dan nonadded value bagi sebuah proses.

Value Stream Mapping sangat erat hubungannya dengan Kaizen. Hal ini dikarenakan setelah dilakukan perbaikan atas proses yang tertuang dalam Value Stream Mapping, akan ada Future Value Stream. 
Future Value Stream menggambarkan proses yang baru. Dengan demikian perlu dilakukan evaluasi terhadap proses yang baru tersebut. Hal seperti mengacu pada prinsip perbaikan berkelanjutan atau Kaizen.

\section{Seven Waste}

Prinsip utama dari pendekatan lean adalah pengurangan atau peniadaan pemborosan (waste) dalam upaya menghilangkan waste, maka sangatlah penting untuk mengetahui apakah waste itu dan keadaan waste tersebut. Ada 7 macam waste yang didefinisikan menurut Sutherland dan Bennett (2007) yaitu :

1. Overproduction (Produksi melebihi demand) Memproduksi lebih banyak dari yang diperlukan atau melebihi demand, membuat lebih dini dari yang diperlukan pada proses berikutnya, atau memproduksi lebih cepat.

2. Delay/Waiting (Waktu menunggu proses berikutnya)

Cara pengolahan batch tradisional dan antrian material siap proses menghabiskan banyak waktu menunggu untuk diolah. Kebanyakan lead time adalah menunggu untuk proses berikutnya, ini dikarenakan aliran material yang buruk.

3. Transportion (Transportasi yang tidak perlu)
Membawa barang dalam proses dalam jarak yang jauh menciptakan angkutan yang tidak efisien atau memindahkan material, komponen, atau barang jadi ke dalam atau ke luar gudang atau antar proses.

4. Space (Ruang yang tidak optimal)

Terdapat penggunaan ruang yang kurang optimal. Dimisalkan, penggunaan ruang gudang yang tidak efisien.

5. Inventory (Persediaan berlebih)

Kelebihan material, barang dalam proses, atau barang jadi menyebabkan lead time yang panjang, barang kadaluarsa, barang rusak, peningkatan biaya pengangkutan dan penyimpanan, dan keterlambatan.

6. Motion Waste (Gerakan yang tidak perlu)

Setiap gerakan yang dianggap tidak perlu saat melakukan pekerjannya seperti mencari, meraih atau menumpuk komponen, alat dan sebagainya.

\section{Error (Terjadi kesalahan)}

Aktivitas apapun yang menyebabkan pengerjaan ulang, terdapat penyesuaian yang tidak perlu.

\section{Interrelationship Diagram}

Interrelationship

diagram

menggambarkan hubungan sebab akibat dari permasalahan yang ditemukan. Menurut Foster 
(2013), Interrelationship

diagram

permasalahan merupakan salah satu tool analisis yang dapat mengidentifikasi sebab dan akibat dari hubungan-hubungan antara berbagai aspek dalam situasi yang kompleks. Melalui interrelationship diagram, kita dapat membedakan isu apa yang merupakan driver (pemicu terjadinya masalah) dan isu apa yang merupakan outcome (akibat dari masalah). Dengan kata lain, diagram keterkaitan merupakan alat untuk menemukan pemecahan masalah yang memiliki hubungan kausal yang kompleks. Hal ini membantu untuk menguraikan dan menemukan hubungan logis yang saling terkait antara sebab dan akibat. Ini adalah proses kreatif yang memungkinkan untuk 'Multi-directional' daripada 'linier' berpikir yang akan digunakan.

Sehingga dengan demikian, alternatif solusi yang muncul tidak untuk menyelesaikan semua permasalahan yang ada. Dengan menemukan akar penyebab masalah yang harus diselesaikan, maka waktu yang diperlukan untuk menyelesaikan semua masalah dapat dipersingkat. Kemudian tool ini biasanya dibuat setelah diagram fishbone atau diagram pohon dengan tujuan lebih memahami hubungan antara ide-ide. Untuk itu, Interrelationship diagram ini membantu penelitian ini dalam menemukan akar penyebab masalah.

\section{Analis is Hirarki Proses}

Teori AHP ini ditemukan oleh

Thomas L. Saaty melalui bukunya The Analytical Hierarchy Process For Decision In

A Complex World. AHP merupakan suatu model pendukung keputusan yang akan menguraikan masalah multi faktor atau multi kriteria yang kompleks menjadi suatu hirarki (Saaty, 1995). Hirarki didefiisikan sebagai suatu representasi dari sebuah permasalahan yang kompleks dalam suatu struktur multi level di mana level pertama adalah tujuan, kemudian diikuti level faktor, kriteria, sub kriteria, dan seterusnya ke bawah hingga level terakhir dari alternatif. Dengan hirarki, suatu masalah yang kompleks dapat diuraikan ke dalam kelompokkelompoknya menjadi suatu bentuk hirarki sehingga permasalahan akan tampak lebih terstruktur dan sistematis.

AHP sering digunakan sebagai metode pemecahan masalah dibandingkan dengan metode lain karena alasan-alasan sebagai berikut : (1) Struktur yang berhirarki, sebagai konsekuensi dari kriteria yang dipilih, sampai pada sub kriteria yang paling dalam ; (2) Memperhitungkan validitas sampai batas 
toleransi inkonsistensi berbagai kriteria dan alternatif yang dipilih oleh pengambil keputusan ; (3) Memperhitungkan daya tahan output analisis sensitivitas pengambil keputusaan.

\section{Analis is Persoalan Potensial (APP)}

Dalam suatu keputusan yang akan diambil tentunya akan dilaksanakan, tetapi terkadang realisasi dalam pelaksanaannya tidak sesuai dengan apa yang direncanakan waktu mengambil keputusan tersebut. Ada kemungkinan dalam pelaksanaannya akan muncul hal-hal yang tidak diinginkan, yang bisa menghambat kelancaran pelaksanaan keputusan. Untuk mengamankan dalam mengimplementasikan suatu rencana akan lebih baik jika menggunakan Analisis Persoalan Potensial.

Analisis Persoalan Potensial berfungsi menganalisis persoalan-persoalan potensial yang mungkin muncul pada saat pelaksanaan keputusan yang telah diambil. Untuk itu sebelum pelaksanaan suatu keputusan, perlu melihat ke depan untuk prediksi persoalanpersoalan yang mungkin mucul. Artinya perlu melihat adakah penyimpangan-penyimpangan yang dapat membatalkan atau mengganggu rencana. Setelah diketahui penyimpangan tersebut, maka sebisa mungkin melakukan upaya pencegahan agar penyimpangan itu tidak terjadi. Selain itu berusaha melakukan tindakan pencegahan dan tindakan proteksi untuk mengantisipasi jika persoalan potensial itu tetap terjadi. Tindakan proteksi efektif bekerja pada saat persoalan potensial terjadi. Agar tindakan proteksi itu cepat efektif bekerja, perlu dipasang sistem informasi pengaktifan. Sistem informasi tersebut harus berisi petunjuk pelaksanaan tindakan proteksi.

\section{METODE RISET}

Jenis penelitian ini merupakan kombinasi antara penelitian yang bersifat kualitatif dan kuantitatif. Hal ini disebabkan data yang digunakan dalam penelitian ini memiliki sifat kualitatif dan kuantitatif. Data bersifat kualitatif merupakan data yang tidak dapat dilakukan operasi hitung, dapat berupa pendapat orang baik secara tertulis ataupun lisan ataupun hasil pengamatan dari obyek yang diteliti. Sementara itu data kuantitatif merupakan data yang berupa angka sehingga dapat dilakukan operasi hitung untuk menghasilkan informasi lain (Walpole, 1997). Untuk memperoleh data kuantitatif, 
pengamatan dapat dilakukan pada sampel maupun populasi dari obyek penelitian.

Dalam peneletian ini, metode pengambilan sampel yang digunakan adalah metode cluster random sampling yang dikombinasikan dengan teknik probability sampling. Cluster Random Sampling merupakan pengambilan sampel dari populasi yang terdiri dari $\mathrm{M}$ kelompok dan dilakukan pemilihan secara acak. Untuk setiap kelompok terpilih diambil sampel secara acak sebanyak $\mathrm{N}$. Teknik probability sampling adalah teknik pengambilan sampel dengan memperhitungkan peluang dari setiap sampel untuk menjadi obyek penelitian.

Penelitian ini menggunakan data primer dan juga data sekunder. Data primer diperoleh dengan cara mengamati proses operasi yang terjadi di lapangan. Sedangkan data sekunder diperoleh dari hasil wawancara dan diskusi dengan pihak terkait dalam sebuah perusahaan jasa bongkar - muat

Kerangka analisis penelitian dapat dilihat dalam gambar dibawah ini:

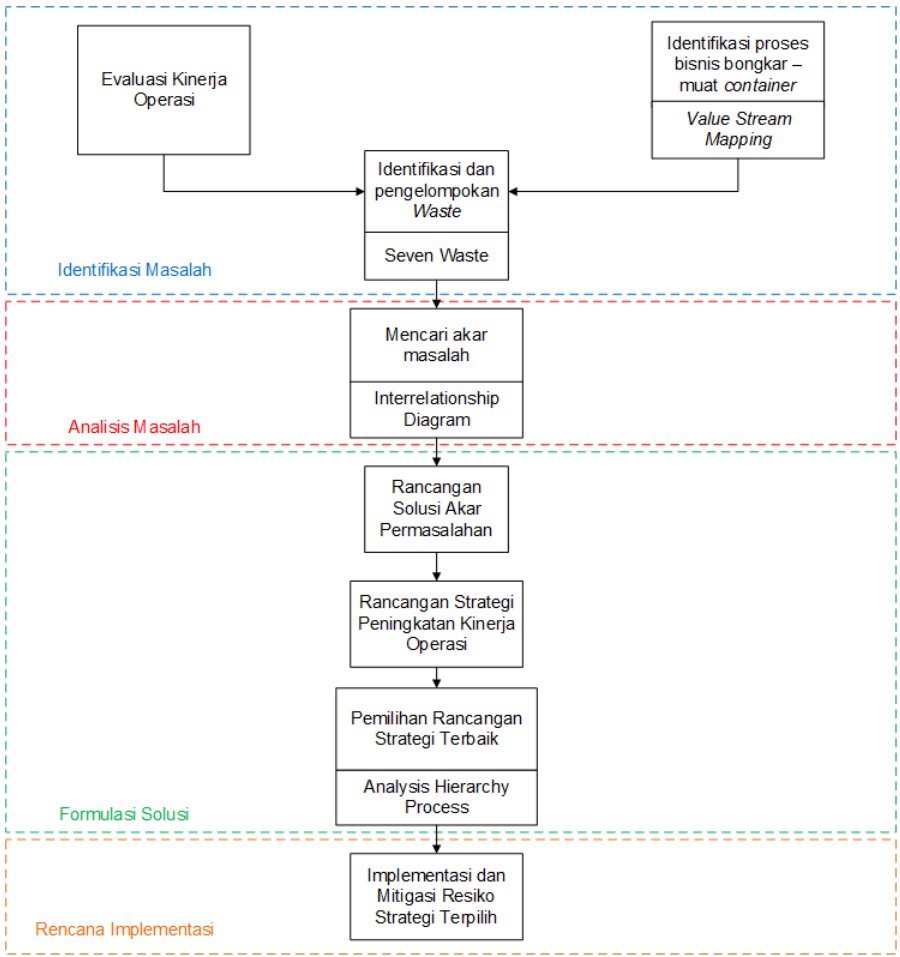

\section{Gambar 1.}

\section{Kerangka Analis is Penelitian}

Kerangka berpikir ini menjelaskan tentang alur kerja yang digunakan dalam penelitian ini. Data yang diperoleh yaitu waktu pelayanan pada alat (CC dan RTG) dan cycle time truk berasal dari internal Divisi Operasi, sementara data customer needs berasal dari eksternal Divisi Operasi, lebih tepatnya Divisi Marketing, akan menjadi landasan evaluasi kinerja selama ini. Di saat yang bersamaan, digunakan analisis Value Stream Mapping untuk memetakan proses bisnis saat ini. Setelah mendapatkan gambaran proses bisnis saat ini dan evaluasi kinerja operasi perusahaan, dilakukan identifikasi dan pengelompokkan waste menggunakan Seven Waste. 
Setelah dilakukan identifikasi dan pengelompokkan waste, dilakukan pencarian akar masalah yang kemudian dipetakan menggunakan Interrelationship Diagram. Setelah diketahui akar persalahannya, dilakukan rancangan alternatif strategi untuk perbaikan kinerja operasi perusahaan. Alternatif strategi yang tersusun akan dipilih satu strategi terbaik menggunakan Analytic Hierarchy Process.

Setelah strategi terpilih, kemudian dibuat rancangan implementasi dan dilakukan mitigasi resiko. Hal ini bertujuan untuk mengetahui potensi hambatan dalam menjalankan strategi terpilih. Dengan demikian, cara menanggulangi masalah yang berpotensi timbul dapat disiapkan sejak dini.

\section{Pengumpulan Data}

Data yang diperoleh dalam penelitian ini bersifat kualitatif dan kuantitatif. Keduanya digunakan baik pada saat melakukan evaluasi kerja atau analisis yang lain. Untuk memperoleh data yang diperlukan, pengumpulan data dilakukan dengan menggunakan metode sebagai berikut:

\section{Data Primer}

Data primer dalam penelitian ini baik yang bersifat kuantitatif maupun kualitatif diperoleh dengan cara melakukan observasi atau pengamatan langsung di lapangan. Pengamatan langsung dilakukan di Dermaga Serbaguna Nusantara (DSN) Tanjung Priok Jakarta. Pengamatan dilakukan pada deck kapal dan juga container yard (CY) yang ada di DSN. Terdapat empat deck kapal di DSN yaitu deck 01, 02, 03, dan 04. Pengamatan lebih terfokus kepada deck 01 dan 02 karena kondisi deck ini yang paling ideal bagi semua jenis kapal.

Selain dengan melakukan pengamatan langsung apa yang terjadi di lapangan, untuk mendapatkan data primer dalam penelitian ini juga dilakukan interview dengan pihak terkait seperti Supervisi, Assisten Manajer, dan Manajer Operasi di lapangan. Interview juga dilakukan dengan pihak Marketing untuk mengetahui data customer satisfaction.

\section{Data Sekunder}

Selain data primer, penelitian ini juga menggunakan data sekunder yang berkaitan. Data sekunder diperoleh dari departemen lain sebagai pendukung dalam penelitian ini seperti Departemen Human Capital, Departemen Marketing, dan lain-lain. Sebagai data pendukung lain, dalam penelitian ini juga digunakan data yang diperoleh dari pustaka 
yang berkaitan dengan bisnis penyedia jasa layanan bongkar - muat container.

\section{PEMBAHASAN}

Hasil penelitian merupakan gabungan dari berbagai metode yang digunakan, yaitu wawancara, survei, dan tinjauan dokumen. Untuk itu ada beberapa analisis pada perusahaan jasa bongkar muat, analisis tersebut adalah :

\section{Analis is Industri}

Menurut Badan Perencanaan

Pembangunan Nasional era pemerintahan Presiden Jokowi, periode 2014-2019, Indonesia menitik beratkan pembangunan pada sektor maritim. Salah satu proyek yang menjadi andalan adalah Proyek Tol Laut. Era pemerintahan Presiden Jokowi berharap bahwa nantinya Indonesia akan menjadi poros maritim dunia pada tahun 2045. Untuk itu pemerintah mendorong perbaikan bagi segala sesuatu yang berkenaan dengan industri maritim Indonesia.

Kedudukan Indonesia yang menjadi poros maritim dunia, bukan hal yang tidak mungkin. Hal ini didukung dengan letak geografis Indonesia yang diapit oleh 2 benua dan wilayah perairan Indonesia yang dilalui jalur perdagangan dunia. Jalur laut masih menjadi primadona karena memiliki total cost yang relatif paling rendah bila dibandingkan dengan jalur udara untuk perdagangan internasional.

Menurut Badan Perencanaan Pembangunan Nasional, terwujudnya harapan Indonesia menjadi poros maritim di tahun 2045 dapat tercapai bila pertumbuhan industri di kawasan Indonesia Timur terus meningkat. Saat ini kondisi industri di kawasan Indonesia Timur masih sangat mahal, sehingga pertumbuhannya sendiri masih kecil. Salah satu yang menyebabkan harga barang-barang di kawasan Indonesia Timur mahal adalah dikarenakan biaya logistik yang masih mahal. Untuk mereduksi mahalnya biaya logistik atau ekspedisi menuju kawasan Indonesia Timur, pemerintah mencanangkan proyek Tol Laut.

Tol Laut adalah konektivitas laut yang efektif berupa adanya kapal yang berlayar secara rutin dan terjadwal dari barat hingga timur Indonesia. Tol laut ini akan menghubungkan pulau-pulau di kawasan Indonesia Timur dan Indonesia Barat baik untuk kapal penumpang maupun kapal pengangkut container. Adapun elemen Tol Laut untuk kapal container menurut Badan Perencanaan Pembangunan Nasional adalah 
sebagai berikut : (1) Pelabuhan yang Handal ;

(2) Kecukupan Muatan dari Barat - Timur, maupun Timur - Barat ; (3) Shipping Industry;

(4) Pelayanan Rutin dan Berjadwal ; (5) Inland akses yang efektif.

Khusus pada elemen Pelabuhan yang Handal, indikator yang perlu dibenahi untuk menunjang proyek Tol Laut yaitu sebagai berikut : (1) Kapasitas terpasang ; (2) Produktivitas ; (3) Efektif Dokumentasi ; (4) Data dan Sistem Informasi : (5) Water Entrance - Inland Transport.

- Institusi Pendukung Indikator-indikator di atas saling
berhubungan untuk dapat mewujudkan pelabuhan yang handal. Apabila kapasitas yang terpasang sudah memadai, dalam hal ini adalah ketersediaan container yard (CY) dan alat-alat yang digunakan, maka hal yang terjadi adalah produktivitas meningkat. Pendokumentasian yang baik juga mewujudkan kehandalan dari sebuah pelabuhan. Terlebih bila pendokumentasian sudah terintegrasi dengan teknologi dan sistem informasi yang canggih. Selain itu, kedalaman dan panjang dermaga yang dikelola juga perlu diperhatikan. Bila memiliki kedalaman yang cukup, maka sangat memungkinkan untuk menyandarkan kapal- kapal yang lebih besar. Dengan demikian daya tampung container bisa menjadi lebih banyak.

Untuk mendukung proyek Tol Laut, pemerintah menyiapkan 24 pelabuhan dan 5 pelabuhan diantaranya menjadi hub atau penghubung dengan pelabuhan-pelabuhan lain. Pelabuhan Hub tersebut yaitu Pelabuhan Belawan / Kuala Tanjung, Pelabuhan Tanjung Priok / Kali Baru, Tanjung Perak, Makassar, dan Bitung. Pelabuhan tersebut menjadi pintu masuk bagi jalur distribusi di seluruh Indonesia.

Dengan dijadikannya Tanjung Priok sebagai Pelabuhan Hub dalam proyek Tol Laut, hal ini menunjukkan adanya peluang bagi perusahaan bongkar - muat di Tanjung Priok. Bertambahnya pelabuhan-pelabuhan di kawasan Indonesia Timur, menjadikan hal ini sebagai peluang bagi Perusahaan Bongkar muat di kawasan Indonesia Barat yang khusus menangani rute pelayaran domestik.

\section{Analisis Value Stream Mapping}

Sebuah perusahaan jasa bongkar muat yang menangani proses bongkar - muat container di pelabuhan Tanjung Priok Jakarta, kegiatan proses bongkar - muat container terdiri dari aktivitas penerimaan container (receiving), pemindahan container dari Container Yard (CY) ke Quay Deck yang 
disebut dengan cargodoring, aktivitas bongkar

- muat itu sendiri (stevedoring), dan aktivitas

pengeluaran container (delivery).

Aktivitas receiving dimulai dari container yang masuk melalui gate in. Pada aktivitas ini dilakukan pencatatan nomor container dan pengecekan dokumen. Selain itu juga dilakukan penimbangan terhadap bobot container yang akan masuk ke dalam terminal. Setelah proses di gate in selesai, truk pembawa container menuju CY untuk melakukan proses receiving selanjutnya yaitu stacking. Proses stacking ini bisa dilakukan oleh dua alat yaitu bisa menggunakan RS maupun RTG.

Aktivitas cargodoring merupakan proses pemindahan container dari CY menuju Quay Deck ataupun sebaliknya. RTG maupun RS menurunkan container dari area stacking untuk diletakkan pada truk yang kemudian dipindahkan.

Aktivitas stevedoring merupakan aktivitas bongkar - muat container dari atau ke kapal. Truk dari CY menuju Quay Deck yang kemudian container akan dipindahkan menggunakan Container Crane yang ada di masing-masing Quay Deck. Kemudian analisis Value Stream Mapping menggambarkan proses bisnis yang berlangsung untuk setiap aktivitas (receiving/delievery atau loading/discharge) yang dapat dilihat pada Lampiran 1-4.

Penggunaan Analisis Value Stream Mapping bertujuan untuk menentukan aktivitas mana yang mengalami pemborosan. Dengan demikian dapat dilakukan effisiensi pada sistem, sehingga dapat meningkatkan produktifitas. Secara garis besar proses aktivitas utama yang dilakukan perusahaan bongkar - muat.

Analisis Value Stream Mapping ini selain menggambarkan proses dalam sistem, juga dapat digunakan untuk melihat pemborosan (waste) yang terjadi di dalam sistem. Apakah perlu ada workstation yang perlu dihilangkan atau dilakukan perbaikan. Hal yang perlu dilakukan adalah pengalokasian sumber daya yang lebih tepat agar kemacetan tidak terjadi dalam sistem. Hal ini bertujuan untuk meminimalisasi terjadinya antrian akibat waktu tunggu yang lama. Seperti yang terlihat pada pengamatan kondisi 25\%, Cycle Time yang diperlukan satu unit truk mencapai 47 menit. Sementara waktu pelayanan dalam sistem sebenarnya hanya membutuhkan waktu 35 menit. Dengan demikian secara kumulatif, satu unit truk dapat kehilangan waktu atau menunggu untuk dilayani fasilitas dalam sistem mencapai 12 menit. Hal ini yang menyebabkan 
kinerja operasi dalam sistem masih belum bisa meningkat.

Perumusan yang tepat dalam pengalokasian sumber daya, dalam hal ini adalah truk menjadi faktor penting dalam peningkatan kinerja operasi perusahaan jasa bongkar - muat dalam mengelola dermaga dan melakukan aktivitas bongkar - muat container. Pemborosan waktu atau waste yang terjadi dalam sistem juga dapat dilakukan dengan melakukan analisis sistem antrian yang terjadi di DSN.

\section{Analis is Sistem Antrian}

Analisis Sistem Antrian digunakan untuk melihat apakah sistem yang dipakai dalam mengelola operasi bisnis sudah berjalan dengan baik atau belum. Sistem antrian ini biasanya akan menghasilkan model yang menggambarkan sistem tersebut bekerja. Kecepatan fasilitas dalam melayani, dalam hal ini adalah RTG di CY dan CC pada QD dapat diukur menggunakan analisis sistem antrian.

Untuk melakukan analisis ini, telah dilakukan pengamatan langsung di lapangan dan dilakukan pencatatan waktu untuk alat-alat yang akan diukur. Disiplin yang digunakan dalam operasi bisnis dalam dermaga menggunakan disiplin First Come First Serve
(FCFS), yaitu pelanggan yang pertama datang yang dilayani terlebih dahulu. Pelanggan dalam konteks ini adalah truk yang digunakan untuk mengangkut container.

Hasil dari analisis sistem antrian adalah ketidakseimbangan antara kemampuan pelayanan alat dengan alokasi truk yang datang mengakibatkan terjadinya idle di salah satu proses, baik itu pada alat (CC atau RTG) ataupun truk yang menunggu untuk dilayani oleh alat. Kondisi menunggu ini membuat sistem menjadi crowded dan terjadi wasting time. Untuk itu kemampuan alat harus seimbang dengan truk yang dialokasikan, sehingga angka yang ditunjukkan pada total pelayanan dan cycle time menghasilkan angka yang sama.

\section{Customer Satisfaction}

Kepuasan pelanggan merupakan hal penting dalam perusahaan jasa, dikarenakan pelanggan yang merasa puas akan menyebarluaskan hal tersebut kepada calon pelanggan lainnya, sehingga akan menaikkan reputasi dari perusahaan jasa tersebut. Perusahaan perlu melakukan survey kepuasan pelanggan tiap tahun. Di mana dengan melakukan survey tersebut perusahaan mendapatkan feedback dari pelanggan sehingga 
dapat membuat strategi untuk memenangkan persaingan di dunia bisnis.

Survey dilakukan terhadap semua pelanggan perusahaan. Hasil dari survey tersebut salah satunya adalah Customer Satisfaction Index (CSI), yaitu suatu indeks yang merefleksikan persepsi satu atau seluruh pelanggan mengenai performansi perusahaan berdasarkan ekspektasi atau harapan mereka. Tren dari angka CSI mengalami penurunan, hal ini harus menjadi perhatian perusahaan agar tren tersebut tidak mengalami penurunan secara terus menerus sampai menjadikan pelanggan tidak puas terhadap performansi perusahaan. Perusahaan juga harus memperhatikan saran dan komentar dari pelanggan untuk meningkatkan kinerja operasi, untuk itu di bawah ini terdapat tabel saran dan komentar pelanggan terhadap perusahaan.

Kemudian dari hasil survey tersebut, beberapa pelanggan memberi komentar dan saranuntuk perusahaan yang perlu diperhatikan. Pelanggan menyebutkan bahwa kecepatan dan waktu bongkar - muat perusahaan masih relatif lama dan kinerja operasi perusahaan masih sama dari pada tahun sebelumnya, serta belum ada kemajuan yang signifikan. Selain itu, pelanggan lain memberi komentar untuk perusahaan perlu meningkatkan produktivitas atau kinerja operasi di lapangan dengan mengamati celah-celah idle yang bisa dihilangkan. Dengan kata lain, pelanggan ingin kinerja perusahaan mengalami peningkatan agar kepuasan pelanggan dapat terpenuhi.

\section{Identifikasi Waste}

Dalam tahap ini yaitu melakukan identifikasi waste di setiap aktivitas operasi yang ada dalam perusahaan. Aktifitas yang teridentifikasi dibagi menjadi empat yaitu aktivitas bongkar (discharge process), muat (loading process), penerimaan container (receiving process), dan pengambilan container (delivery process). Pada value stream mapping terdapat penggambaran aktifitas yang di satukan dan terjadi di lapangan, sehingga waste yang terjadi pada aktifitas tersebut menjadi tidak spesifik. Oleh karena itu, diperlukan observasi lebih dalam untuk setiap aktifitasaktifitas ini.

Pengelompokan waste berdasarkan tujuh kategori waste adalah sebagai berikut : (1) Waiting ; a. Waktu muat lama, dikarenakan ada permintaan extend closing dari pelanggan ; b.

Divisi marketing tiba-tiba memberikan loading list, sehingga menyebabkan kegiatan muat ke dalam kapal beroperasi lagi menunggu truk 
pelanggan datang ; c. Truk menunggu untuk dilayani RTG dalam receiving and delivery process; (2) Transportation; a. Lalu lintas di lapangan crowded, dikarenakan terlalu banyak truk di lapangan : b. Terjadi antrian truk untuk dilayani oleh RTG ; c. Terjadi antrian truk untuk dilayani oleh CC ; (3) Space. Container hasil bongkaran ditumpuk bercampur dengan container muatan ; (4) Motion. Terjadi angsur container akibat container bercampur antara bongkaran dan muatan ; (5) Error. Wifi sering error, sehingga menyebabkan input data terganggu.

Hasil temuan waste tersebut dapat dikelompokan berdasarkan permasalahan yang ada yaitu masalah yang ada di CY, masalah pada truk, adanya masalah order dariklien yang meminta extend closing, dan juga masalah teknis pada jaringan internet. Selanjutnya akan dilakukan analisis menggunakan interrelationship diagram untuk mengetahui akar penyebab dari masalah yang dihadapi.

\section{Pemetaan Akar Penyebab Masalah}

Pemetaan ini dilakukan berdasarkan hasil analisis seven waste, pengamatan di lapangan, melakukan brainstorming dengan para stake holder, dan analisis yang logis terhadap masalah-masalah yang ditemukan.

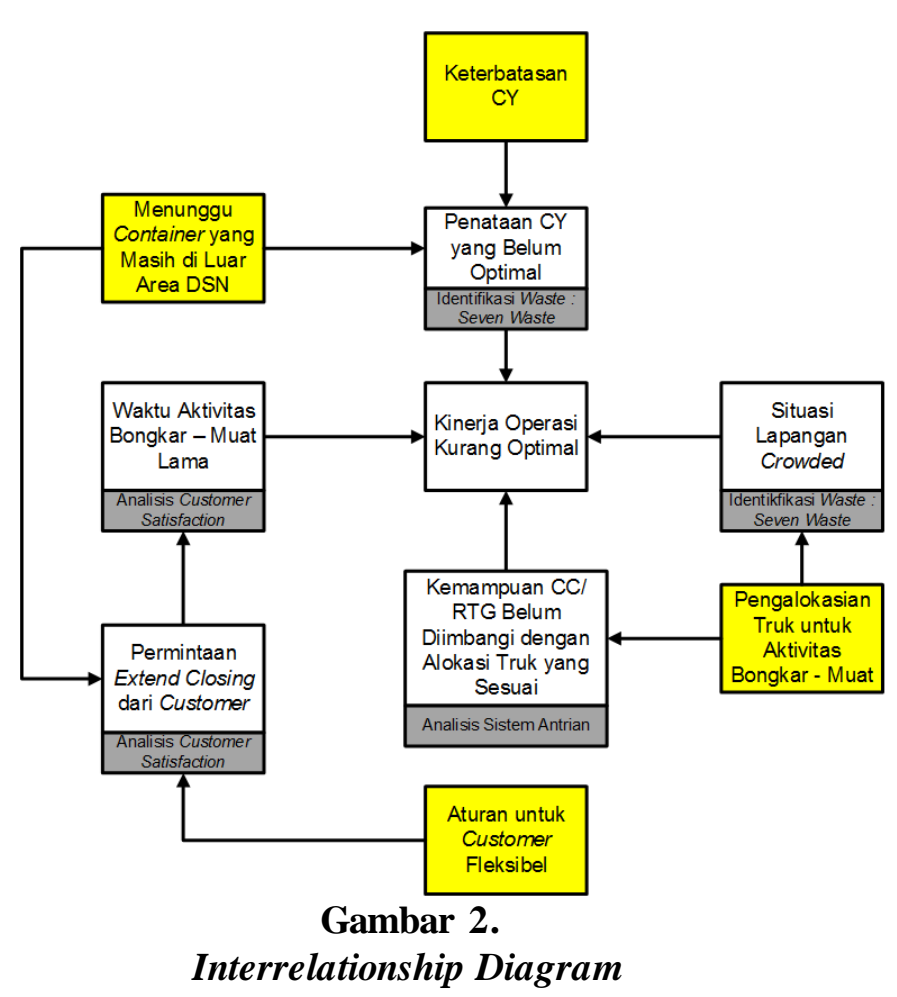

Gambar di atas menunjukkan masalahmasalah yang berdampak pada kinerja operasi perusahaan. Berdasarkan Gambar 2, kinerja operasi yang kurang optimal disebabkan oleh beberapa masalah, di antaranya adalah situasi lapangan yang crowded, kemampuan CC/RTG belum diimbangi dengan alokasi truk yang sesuai, waktu aktivitas bongkar - muat yang dirasa masih memerlukan waktu yang lama, dan penataan Container Yard (CY) yang belum optimal. Masalah-masalah tersebut tidak muncul dengan sendirinya, namun disebabkan karena adanya masalah-masalah lain.

Untuk masalah belum teralokasinya truk yang belum sesuaidengan kemampuan alat CC maupun RTG dan situai lapangan yang 
crowded, disebabkan oleh masalah pengalokasian truk untuk aktivitas bongkar muat yang belum sesuai. Saat ini terdapat 20 unit Terminal Truck yang digunakan untuk menjalankan aktivitas bongkar - muat di Dermaga Serbaguna Nusantara (DSN). Untuk aktivitas bongkar - muat setiap kapal yang sandar memiliki kapasitas box yang berbeda. Dengan demikian pengalokasian terminal truk yang digunakan juga harus disesuaikan dengan jumlah box yang dibawa oleh kapal. Selain itu kondisi lapangan juga harus dipertimbangkan, agar tidak terjadi kemacetan dan menimbulkan situasi crowded di lapangan. Kondisi ini dapat dilihat dari jumlah kapal yang bersandar untuk setiap aktivitas.

Masalah lain yang menyebabkan kinerja operasi kurang optimal adalah masalah aktivitas bongkar - muat yang dirasa memerlukan waktu yang lama. Masalah ini disebabkan karena adanya permintaan extend closing dari customer. Extend closing adalah penambahan waktu pengerjaan aktivitas (biasanya aktivitas muat) akibat menunggu container yang masih berada di luar area dermaga. Container yang berada di luar dermaga artinya tidak berada di CY dan biasanya container ini berjenis container reefer.
Container reefer adalah container yang didesain khusus untuk mengangkut barangbarang yang tidak bisa bertahan lama seperti es krim, daging, dan sebagainya, sehingga tidak memungkinkan untuk ditumpuk di CY.

Kemudahan customer melakukan extend closing disebabkan karena aturan yang diberikan perusahaan kepada customer dirasa masih terlalu fleksibel. Hal ini dilakukan oleh Divisi Marketing, karena fleksibilitas dalam pengajuan extend closing, menjadi order winner bagi perusahaan dalam melakukan bisnis operasi bongkar - muat di Pelabuhan Tanjung Priok. Para customer juga tidak keberatan untuk membayar charge yang diberikan akibat pengajuan extend closing yang dilakukan.

Permasalahan dari menunggu container yang masih berada di luar dermaga juga menyebabkan masalah pada penumpukan container di CY yang kurang optimal. Walaupun sudah diberikan aturan bahwa container yang akan dimuat harus sudah berada di CY DSN pada H-5 sampai dengan H-1 kapal sandar, namun pada kenyataannya container yang masuk ke DSN bisa masuk pada saat aktivitas sudah dikerjakan. Hal ini dilakukan dengan cara customer juga melampirkan 
dokumen loading list yang terbaru. Selain itu masalah penataan lapangan yang kurang optimal juga disebabkan oleh bentuk lapangan yang tidak ideal. Idealnya lapangan penumpukan dan dermaga berbentuk segi empat, sehingga penataan layout bisa dilakukan dengan maksimal.

Dengan kondisi lapangan yang terbatas dan kurang ideal sebagai lapangan penumpukan, hal ini menjadi kendala tersendiri bagi perusahaan. Terlebih lapangan tersebut digunakan untuk aktivitas bongkar dan muat. Sehingga, container untuk aktivitas bongkar dan muat tertumpuk menjadi satu di satu area. Dengan bertumpuknya container untuk aktivitas bongkar dan muat yang berada pada satu area, hal ini membuat terkadang RTG harus melakukan angsur container yang lebih lama. Akibatnya adalah terminal truk harus menunggu waktu yang lebih lama.

Dengan demikian berdasarkan Gambar 2 akar penyebab masalah dari kinerja operasi perusahaan yang kurang optimal terdapatempat akar masalah yang sudah dijabarkan di atas. Untuk itu perlu dilakukan perbaikan untuk menyelesaikan masalah-masalah yang ada agar kinerja operasi dapat meningkat.

Kemudian berdasarkan akar penyebab masalah yang dihadapi oleh perusahaan, maka dibuat rancangan strateginya yaitu:

\section{Strategi CRM}

Salah satu akar masalahnya adalah customer dapat dengan mudah melakukan extend closing yang disebabkan karena aturan perusahaan kepada customer dirasa masih terlalu fleksibel, sehingga menyebabkan akar masalah yang kedua yaitu menunggu container yang masih di luar area DSN karena ada permintaan extend closing. Tetapi para customer juga tidak keberatan untuk membayar charge yang diberikan akibat pengajuan extend closing tersebut. Jika perusahaan menghapus extend closing, maka dapat dikhawatirkan perusahaan akan kehilangan customer. Akan tetapi jika tetap dipertahankan seperti kondisi saat ini, perusahaan harus menunggu container dari luar untuk masuk ke area DSN, maka untuk target kinerja operasi sulit tercapai.

Kemudian dilihat juga berdasarkan tipe-tipe pelanggan perusahaan hanya $37.5 \%$ pelanggan yang termasuk kategori apostles (puas dan loyal), dan sisanya berpotensi untuk pindah memakai jasa perusahaan bongkar-muat lainnya. Untuk itu dalam penelitian ini menyarankan strategi Customer Relationship Management (CRM). Menurut Kalakota dan 
Robinson (2001), target dari CRM berfokus pada tiga hal, yaitu : (1) Mendapatkan pelanggan baru (acquire); (2) Meningkatkan hubungan dengan pelanggan yang ada (enhace); (3) Mempertahankan pelanggan (retain).

Target CRM pertama menurut Kalakota dan Robinson (2001) adalah fokus mendapatkan pelanggan baru. Pelanggan baru bisa dilihat daripeluang analisis industri saat ini adalah Tol Laut. Saat ini sampai dengan tahun 2019 sedang dilaksanakan pembangunan dan pengembangan pelabuhan-pelabuhan di seluruh Indonesia, totalnya terdapat 24 pelabuhan. Rute pelanggan perusahaan saat ini adalah industri pelayaran yang melayani permintaan area Indonesia Barat. Untuk itu ada peluang mencari pelanggan baru yang melayani area Indonesia bagian Timur.

Dikarenakan akar masalahnya adalah aturan extend closing untuk pelanggan yang ada tidak ketat, maka yang terkait dalam hal ini yaitu target CRM menurut Kalakota dan Robinson (2001) yaitu target bagian kedua dan ketiga. Target tersebut adalah meningkatkan hubungan dengan pelanggan yang ada dan mempertahankan pelanggan tersebut. Strategi untuk hal ini adalah membuat website perusahaan, di mana fungsi website yang dirancang itu selain dapat mengetahui informasi umum tentang perusahaan, website tersebut juga berguna untuk mengetahui informasi jadwal kapal sandar dan status keberadaan container pelanggan. Dikarenakan perusahaan mengelola Dermaga sendiri dan tidak tergantung pada PT. Pelindo II, sehingga perusahaan dapat memberikan kepastian jadwal kapal sandar kepada pelanggan. Biasanya untuk memberikan informasi jadwal kapal sandar menggunakan via telepon. Jika website dibuat, maka perusahaan dapat memperbaharui jadwal kapal sandar dan pelanggan dapat dengan mudah mengakses informasi terkini.

Website tersebut juga sebagai wadah interaksi antara perusahaan dan pelanggan. Website juga harus dibuat secara menarik, agar pelanggan baru mau memakai jasa perusahaan ini. Selain itu dengan adanya website yang mempermudah pelanggan dalam pemesanan jasa, maka pelanggan akan melihat sebagai perusahaan yang modern dibanding perusahaan lain yang dalam pemesanannya tidak menggunakan teknologi.

Kemudian aturan yang berlaku untuk para pelanggan tidak akan mungkin langsung merubah aturan extend closing atau menghilangkan extend closing, karena 
pelanggan akan bisa berpindah ke perusahaan lain. Hal ini bisa disiasati dengan pelanggan dalam hal memesan atau meminta jadwal bongkar-muat via website. Selain itu aturan extend closing untuk pelanggan memakai aturan yang baru yang sudah diperketat. Bahwa batasan untuk perubahan loading list (permintaan extend closing) harus 1 hari sebelum kapal sandar di dermaga, tidak seperti saat ini yang dalam merubah loading list di waktu kapal sudah bersandar dan perusahaan sedang melakukan operasinya. Dengan adanya demikian, terdapat aturan selanjutnya untuk menetapkan kejelasan bahwa menetapkan waktu kedatangan container ke DSN, sehingga akan terselesaikan masalah menunggu container di luar area DSN karena adanya permintaan extend closing secara mendadak. Selain itu dalam website tersebut juga sudah tercantum tarif extend closing jika pelanggan menginginkannya.

\section{Strategi Split Area}

Terdapat akar penyebab masalah mengenai keterbatasan container yard (CY) dan pengalokasian truk yang digunakan untuk aktivitas bongkar - muat. Strategi split area digunakan untuk menyelesaikan permasalahan mengenai $\mathrm{CY}$.
Strategi split area adalah dengan memisahkan area CY untuk aktivitas bongkar dan muat. Saat ini area CY untuk aktivitas bongkar dan muat masih menjadi satu area. CY saat ini hanya dibedakan berdasarkan rute pelayaran, namun tidak dibedakan jenis aktivitasnya. Hal ini menyebakan RTG sering mengalami double job, yang artinya pada saat melayani truck untuk aktivitas muat, RTG juga melayani truk customer untuk aktivitas delivery. Aktivitas delivery ini adalah aktivitas yang terjadi setelah aktivitas bongkar selesai. Ketika aktivitas bongkar selesai, maka truck dari customer datang ke DSN untuk mengambil container. Untuk itu RTG yang sedang melakukan pelayanan terhadap truck untuk aktivitas muat dapat terganggu karena harus melayani truck dari customer yang mengambil container.

Pemisahan container untuk aktivitas bongkar dan muat dapat dilakukan dengan menambahkan area buffer untuk container bongkaran. Area buffer ini digunakan untuk aktivitas bongkar. Hal ini dikarenakan container hasil bongkaran tidak berada di CY terlalu lama. Biasanya hanya 1 hari berada di CY atau paling lama 3 hari sudah diambil oleh pemilik container. 
Pelayanan RTG untuk aktivitas bongkar atau muat yang sering terganggu oleh aktivitas receiving dan delivery dapat diatasi dengan optimalisasi Reach Stacker (RS). RTG difokuskan untuk menangani aktivitas bongkar dan muat, sementara RS digunakan untuk melayani truck dari customer pada aktivitas receiving dan delivery.

\section{Strategi Truck Allocation}

Strategi selanjutnya adalah dengan optimalisasi alokasi truk yang digunakan dalam setiap aktivitas. Berdasarkan analisis yang telah dilakukan yaitu mulai dari pemetaan masalah, pemetaan proses bisnis, dan analisis sistem antrian, masalah yang timbul di dalam mengelola Dermaga Serbaguna Nusantara dan menjalankan bisnis bongkar - muat container adalah pengalokasian truk yang kurang tepat. perusahaan memiliki 20 terminal truk untuk keperluan aktivitas bongkar - muat di DSN. Namun pengalokasian truk yang digunakan pada saat aktivitas bongkar - muat masih belum terstandarisasi.

\footnotetext{
Rancangan perbaikan ini dilakukan untuk menentukan penggunaan truk yang seharusnya digunakan, agar target $\mathrm{BCH}$ yang diinginkan dapat tercapai. Bila melihat keandalan operator RTG ataupun CC,

peningkatan target kinerja operasi masih memungkinkan. Namun pengalokasian atau penggunaan truk dalam menjalankan aktivitas masih bekerja optimal. Masih sering terjadi over resources atau under resourcing pada pengalokasian truk.

Rancangan perbaikan untuk kinerja operasi ini akan dituangkan dalam rumus matematis agar memperoleh truk optimal dalam aktivitas bongkar - muat container. Rumus ini diperoleh berdasarkan analisis sistem antrian dan melihat kapasitas DSN dalam bongkar muat container. Rumus berikut didesain untuk dapat mengukur pengalokasian truk baik untuk setiap kapal sandar atau perencanaan kapal sandar dalam satu bulan ke depan. Bila digunakan untuk perencanaan satu bulan ke depan, maka divisi operasi perlu bekerja sama dengan divisi marketing untuk melakukan forecast, berapa banyak container yang akan ditangani pada bulan yang akan datang. Berikut adalah rumus yang diberikan untuk mendapatkan banyaknya truk optimal yang digunakan:

\section{Langkah 1}

$$
\text { Takt Time }=\frac{\text { Jumlah Box }(\text { Container })}{\text { Target } B C H}
$$


Takt Time adalah waktu efektif yang tersedia untuk melakukan aktivitas bongkar

- muat.

\section{Langkah 2}

Banyaknya Cycle Time Truk

$$
=\frac{\text { Takt Time } \times 60}{\text { Waktu Cycle Time }}
$$

Dari waktu efektif yang tersedia, maka dicari banyaknya Cycle Time untuk masing - masing truk.

\section{Langkah 3}

\section{JumlahTruk}

$$
=\frac{\text { Jumlah Box }(\text { Container })}{\text { Banyaknya Cycle Time }}
$$

Jumlah truk optimal akan diperoleh dari jumlah container yang akan ditangani dibagi dengan banyaknya Cycle Time yang akan dialami oleh tiap truk.

Rumus ini dapat digunakan sebagai acuan dalam menentukan penggunaan truk optimal. Adapun asumsi yang digunakan adalah rata-rata kinerja dari operator sesuai dengan hasil pengamatan di lapangan, dan proses pelayanan truk tidak terganggu dengan aktivitas receiving maupun delivery. Bila terjadi aktivitas receiving maupun delivery, maka akan terjadi perubahan pada Cycle Time pada truk. Tujuan dari rumus ini selain mendapatkan komposisi truk optimal juga mensimulasikan sistem dengan waktu tunggu yang lebih singkat. Pemilihan Strategi

Dalam penelitian ini menggunakan Analisis Hirarki Proses (AHP) untuk memilih alternatif urutan strategi yang akan digunakan. Sebelumnya telah dijelaskan bahwa terdapat 3 buah rancangan strategi guna meningkatkan kinerja operasi perusahaan. Selain itu strategi tersebut juga digunakan untuk menyelesaikan akar-akar penyebab masalah yang ada.

$$
\text { Rancangan strategi yang telah }
$$
dikemukakan sebelumnya akan dilakukan secara berurutan hingga tahun 2020. Berdasarkan logika matematika sederhana, urutan untuk menjalankan strategi tersebut terdapat 6 kemungkinan. 6 kemungkinan tersebut disajikan ke dalam alternatif-alternatif. Urutan yang ditunjukkan dari masingmasing alternatif menunjukkan rancangan strategi mana yang akan dikerjakan terlebih dahulu hingga tahun 2020.

Untuk mencapai tujuan yaitu meningkatkat target kinerja operasi perusahaan, diperlukan 4 kriteria dalam memilih alternatifalternatif yang ada. Kriteria tersebut adalah sebagai berikut : (1) Tingkat Kemudahan. Tingkat kemudahan diukur berdasarkan 
seberapa mudah alternatif urutan rancangan strategi dapat dilakukan. Alternatif yang dirasa paling mudah akan mendapat bobot paling besar ; (2) Tingkat kecepatan. Tingkat kecepatan diukur berdasarkan waktu implementasi rancangan perbaikan. Jadi, rancangan perbaikan yang dapat dilakukan terlebih dahulu akan mendapat bobot yang lebih besar; (3) Signifikansi dampak. Hal ini diukur dari dampak yang dapat dirasakan setelah implementasi perbaikan dilakukan. Alternatif dengan urutan yang memiliki dampak lebih besar akan mendapat bobot lebih besar ; (4) Biaya. Kriteria biaya diukur dari seberapa murah investasi yang harus dikeluarkan dalam menjalankan rancangan perbaikan. Investasi yang lebih murah akan mendapat bobot lebih besar.

Berdasarkan hasil AHP menggunakan bantuan software Expert Choice 11, dari keempat kriteria tersebut diperoleh hasil sebagaimana tertera dalam gambar 3 .

Gambar 3 menunjukkan bobot yang diperoleh dari hasil Analisis Hirarki Proses dengan bantuan software Expert Choice 11. Pada Gambar 3 terlihat bahwa kriteria Signifikansi Dampak memiliki prosentase paling tinggi yaitu $47.8 \%$ yang artinya kriteria

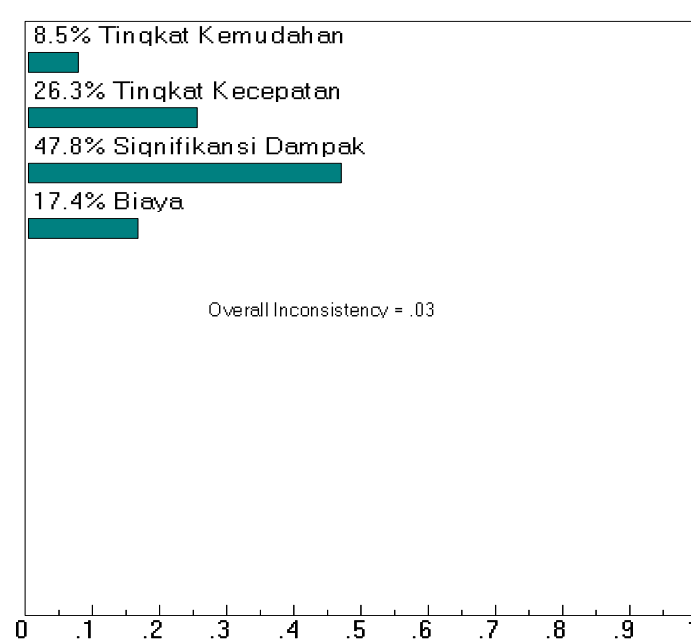

Gambar 3.

Bobot kriteria menggunakan AHP

ini menjadi kriteria paling penting dalam memilih alternatif urutan rancangan perbaikan yang sudah dijelaskan sebelumnya. Setelah signifikansi dampak, bobot terbesar kedua adalah kriteria Tingkat Kecepatan yaitu 26.3\%. Hal ini menunjukkan bahwa dalam pengaplikasian urutan rancangan perbaikan kriteria yang paling penting adalah dampak yang diberikan terhadap kinerja operasi dan urutan rancangan perbaikan yang memiliki implementasi lebih cepat. Hasil pembobotan kriteria dari AHP dirasa sudah sangat cocok mengingat rancangan perbaikan akan dilakukan dalam waktu yang relatif singkat yaitu 3 tahun atau sampai dengan 2020.

Setelah melakukan pembobotan terhadap kriteria untuk mencapai tujuan akhir, selanjutnya adalah melakukan pembobotan alternatif urutan yang sudah dijelaskan. 
Pembobotan ini dilakukan berdasarkan pertimbangan atas bobot kriteria yang sudah dilakukan.

Hasil AHP menggunakan bantuan software Expert Choice 11, menunjukkan bahwa alternatif urutan keenam yaitu memiliki bobot paling besar yaitu 27.7\%. Hasil Analisis Hirarki Proses ini memiliki tingkat konsistensi sebesar 97\%. Dengan demikian urutan rancangan perbaikan yang harus dilakukan sampai dengan tahun 2020 adalah melakukan rancangan perbaikan Allocation Truck terlebih dahulu. Kemudian rancangan perbaikan yang dilakukan adalah Split Area dan yang terakhir adalah strategi CRM. Hasil ini telah dikonfirmasi dengan Manajer Operasi bahwa bobot tertinggi untuk alternatif strategi yang memiliki dampak paling besar dan strategi yang paling mungkin cepat dilaksanakan.

\section{Implementasi Strategi}

Dalam penerapan urutan alternatif strategi terpilih, terdapat pihak yang terlibat selain Divisi Operasi. Hal ini dilakukan karena untuk mencapai tujuan diperlukan sinergi antara Divisi Operasi dengan divisi lain. Setidaknya dalam menjalankan alternatif strategi diperlukan 3 divisi yang terlibat yaitu Operasi, Marketing, dan IT.
Tugas dari Divisi Operasi dalam menjalankan strategi terpilih adalah sebagai berikut : (1) Melakukan audit alat (RTG, RS, CC, dan Truk) ; (2) Membuat lembar kerja strategi Allocation Truck ; (3) Melakukan Uji coba strategi Allocation Truk ; (4) Melakukan Evaluasi terhadap strategi allocation Truck; (5) Melakukan audit terhadap CY ; (6) Melakukan Redesign Layout CY ; (7) Membuat kontrak kerja sama dengan Transkorindo ; Melakukan uji coba strategi Split Area ; (9) Melakukan evaluasi terhadap strategi Split Area; (10) Membuat aturan mengenai extend closing.

Selain Divisi Operasi, Divisi Marketing juga terlibat dalam pelaksanaan rancangan strategi dengan tugas sebagai berikut : (1) Mencari pelanggan baru dengan rute pelayaran Indonesia Timur ; (2) Menyiapkan konsep website; (3) Menyiapkan konten website.

Divisi terakhir yang terlibat dalam pelaksanaan strategi terpilih ini adalah Divisi IT. Tugas divisi IT dalam pelaksanaan terpilih ini adalah sebagai berikut : (1) Mencari vendor website developer; (2) Menyiapkan database untuk website ; (3) Melakukan controlling 
pembuatan website ; (4) Melakukan soft launching website.

\section{KESIMPULAN DAN SARAN}

\section{Kesimpulan}

Setiap perusahaan jasa bongkat - muat dituntut memiliki kinerja yang optimal dalam menjalankan operasi bisnisnya. Untuk itu perusahaan mempunyai target 3 tahun ke depan yaitu di tahun 2020 untuk dapat meningkatkan kinerja operasi $3 \mathrm{BCH}$.

Setelah dilakukan analisis terhadap kinerja operasi perusahaan, terdapat empat akar masalah yang terjadi di perusahaan, yaitu adanya keterbatasan container yard yang dimiliki, pengalokasian truk yang kurang tepat untuk aktivitas bongkar - muat, aturan untuk pelanggan terlalu fleksibel, dan operasi terhambat karena sering menunggu container yang masih belum datang. Dengan adanya beberapa masalah maka disusun tiga strategi untuk menyelesaikan masalah tersebut, yaitu :

(1) Allocation Truck. Allocation Truck adalah strategi penggunaan truk dalam aktivitas bongkar - muat menggunakan rumus ; (2) Split Area. Split Area merupakan strategi pemisahan CY untuk aktivitas bongkar dan muat guna meningkatkan efisiensi RTG di CY ; (3) CRM
CRM adalah strategi yang digunakan untuk meningkatkan customer satisfaction index (CSI) dan mendapatkan pasar baru dengan rute Indonesia bagian Timur.

Rancangan strategi di atas akan dilakukan secara berurutan hingga tahun 2020 . Berdasarkan logika matematika sederhana, urutan untuk menjalankan strategi tersebut terdapat 6 kemungkinan alternatif-alternatif.

Kemudian untuk mencapai target peningkatan kinerja operasi, diperlukan 4 kriteria dalam memilih alternatif-alternatif yang ada. Kriteria tersebut adalah sebagi berikut : (1) Tingkat Kemudahan ; (2) Tingkat kecepatan; (3) Signifikansi dampak; (4) Biaya. Berdasarkan hasil Analisis Hirarki Proses (AHP) menggunakan bantuan software Expert Choice 11, strategi terpilih dijalankan dalam jangka waktu 3 tahun atau 2017 - 2020. Rancangan strategi tersebut dijalankan berurutan sesuai dengan timeline yang sudah dibuat dalam rancangan implementasi strategi.

\section{Saran}

a. Bagi Perusahaan

Supaya strategi terpilih dapat berjalan dengan baik, maka hal yang perlu diperhatikan adalah pengawasan terhadap pelaksanaan strategi. Bila dilihat dari Network Planning, 
strategi ini memiliki waktu yang cukup padat.

Untuk pengawasan yang intensif dapat membantu strategi ini berjalan dengan lancar.

Selain itu untuk mengimplementasikan strategi terpilih, diperlukan sumber daya manusia yang cukup berkompeten. Disarankan untuk para manajer dan supervisor di lapangan dapat melakukan pendekatan dan memberikan arahan yang jelas.

b. Bagi Akademisi

Untuk penelitian selanjutnya harap diperhatikan dalam pengambilan sampel pada saat pengamatan di lapangan. Teknik pengambilan sampel dapat menggunakan stratified random sampling berdasarkan satuan waktu. Hal ini bertujuan untuk menghindari bias dari sampel yang dihasilkan karena adanya tren waktu tertentu. 


\section{DAFTAR PUSTAKA}

Deragon, J. (2011, Maret 25). strategic faktors created by social media. Retrieved 05 19, 2016, from www.relationship-economy.com: http//www.relationship-economy.com/2011/03/strategicfaktors-created-by-social-media/

Foster, S. T. (2013). Managing Quality : Integerating Supply Chain. England: Person Education Limited.

George, M. L. (2002). Lean Six Sigma. United States: McGraw-Hill.

Gross, D., \& Harris, C. (1994). Fundamental of Queueing Theory (Third ed.). New York: Wiley Interscience.

Harrell, C. R., \& Tumay, K. (1995). Simulation Made Easy: A Managers Guide. (M. Reeves, Ed.) United States: Ellen Snodgrass.

Hiller, F., \& Lieber, G. (2001). Introduction to Operation Research (Seventh ed.). New Jersey: Mc Graw - Hill.

Murthy, P. (2007). Operation Research (Second ed.). New Delhi: New Age International.

Myerson, P. (2012). Lean Supply Chain and Logistics Management. United States: McGraw Hill.

Ravindran, A., Phillips, D. T., \& Solberg, J. J. (1987). Operations Research : Principles and Practice (Second ed.). New York: John Wiley and Sons, Inc.

Robinson, \& Kalakota. (2001). E-Business 2.0 : Roadmap For Success. New Jersey: Addison.

Ross, S. (1966). Stochastic Processes. New York: John Wiley and Sons, Inc.

Sasieni, M., Yaspan, A., \& Friedman, L. (1959). Operations Research: Methods and Problems. New York: John Wiley and Sons, Inc.

Saaty, T. L. (1995). The Analytical Hierarchy Process for Decision in A Complex World. Pittsburgh : University of Pittsburgh.

Sudiyanto. (2008). Perkembangan Industri Jasa Transportasi Laut. Retrieved 12 18, 2016. www.datacon.co.id/Angkutanlaut2008Ind.html.

Sutherland, J., \& Bennett, B. (2007). The Seven Deadly Wastes of Logistics : Applying Toyota Production System Principkes to Create Logistics Value. 3-4.

Syaifullah. (2010). Pengenalan Metode AHP (Analytical Hierarchy Process). Retrieved 12 18, 2016. https://syaifullah08.files.wordpress.com.

Trivitas, F.P. (2015). Analisis Eksistensi Perusahaan Bongkar Muat dalam Konteks Pelayanan Transportasi Laut - Studi Kasus : Tanjung Perak. Journal of Marine Engineering. Surabaya : ITS

Walpole, R. E. (1997). Pengantar Statistika (3 ed.). Jakarta: Gramedia Pustaka Utama.

Winston, W. (2003). Operations Research Applications and Algorithm (4th ed.). United States: Duxbury Press.

Zylstra, K. D. (2006). Lean Distribution. Jakarta:Penerbit PPM. 
Journal of Management Vol.15, No. 1, 2018 : 1-32

\section{Lampiran 1. Current Value Stream Mapping Discharge Process}
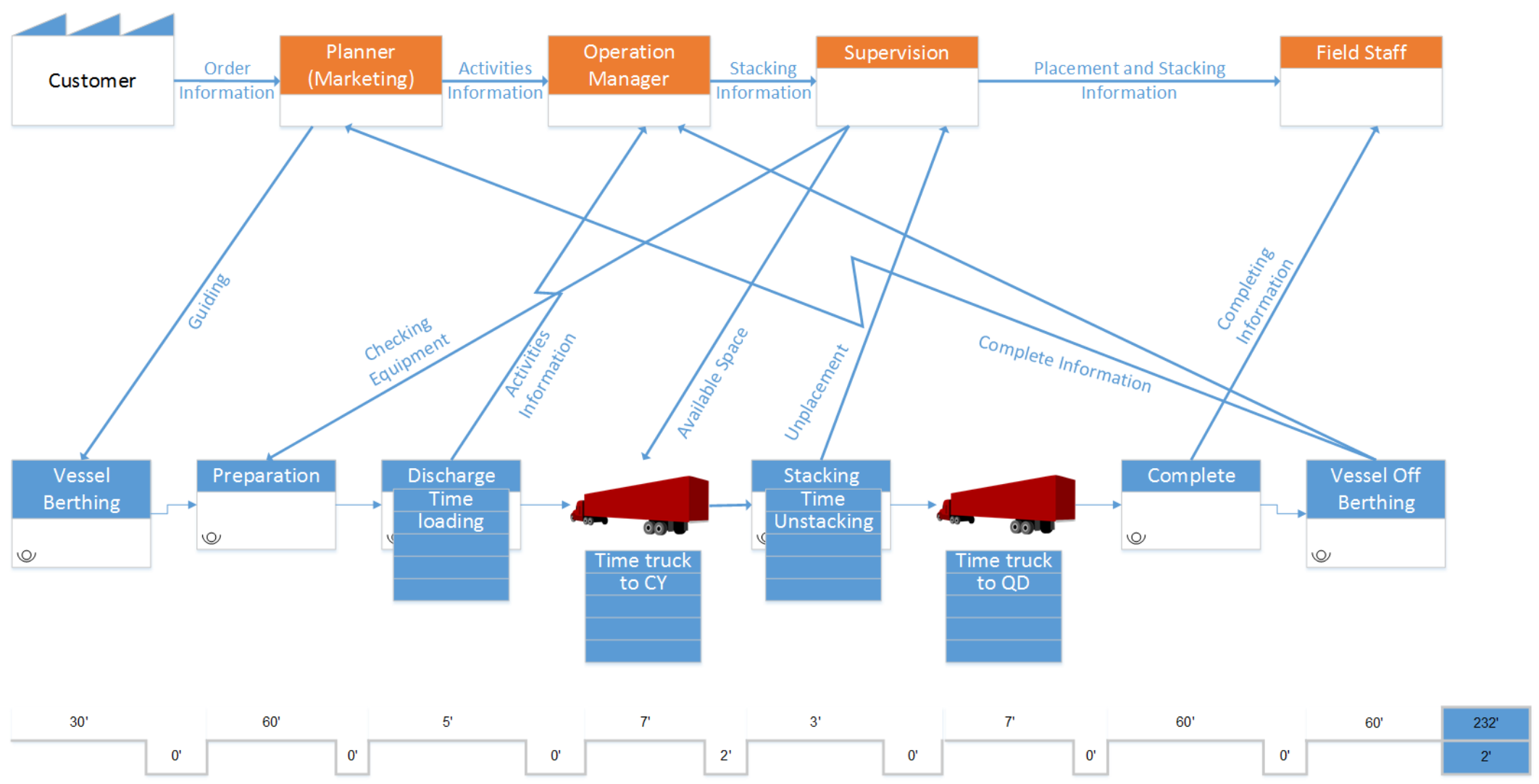


\section{Lampiran 2. Current Value Stream Mapping Loading Process}

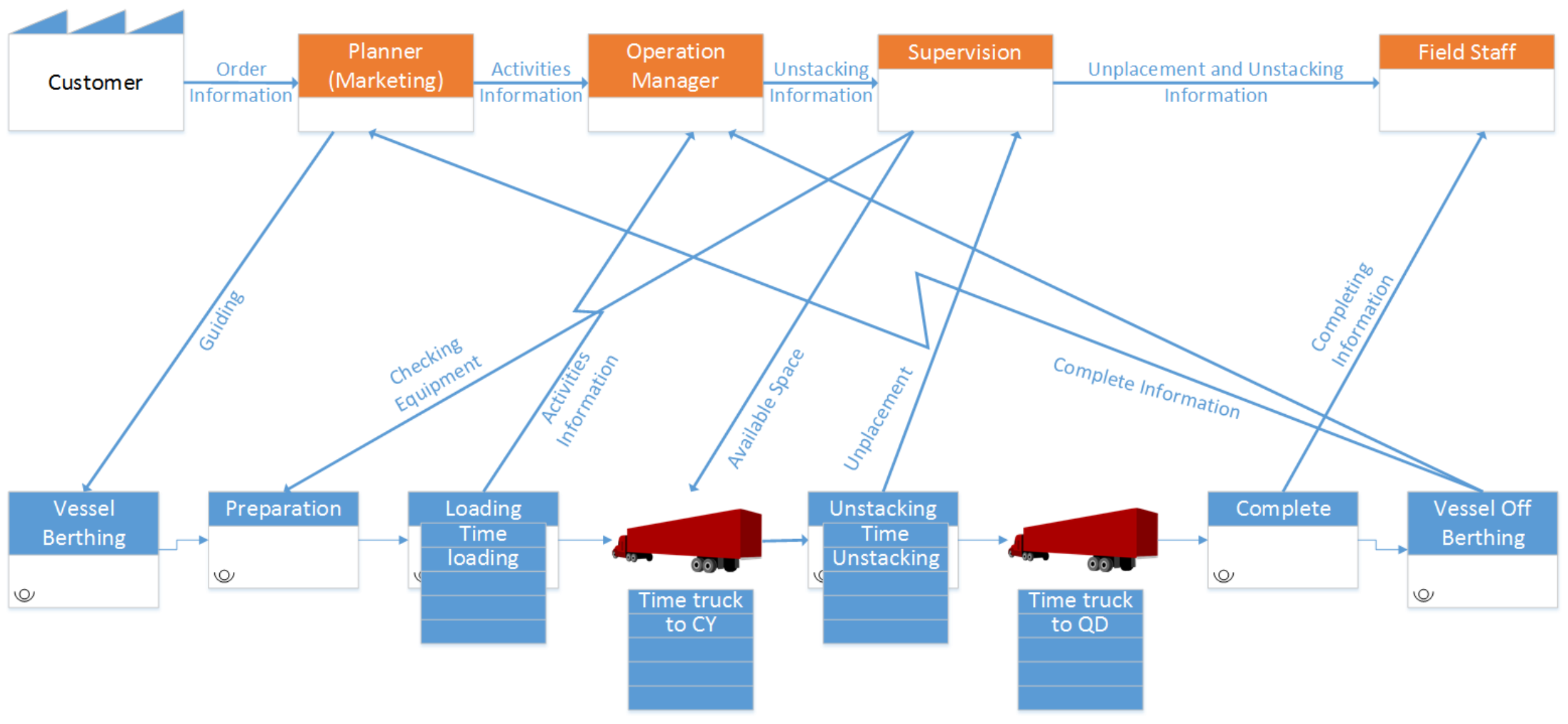

\begin{tabular}{|l|l|l|l|l|l|l|l|l|l|}
\hline $30^{\prime}$ & $60^{\prime}$ & $5^{\prime}$ & $3^{\prime}$ & $7^{\prime}$ \\
\hline
\end{tabular}




\section{Lampiran 3. Current Value Stream Mapping Receiving Process}

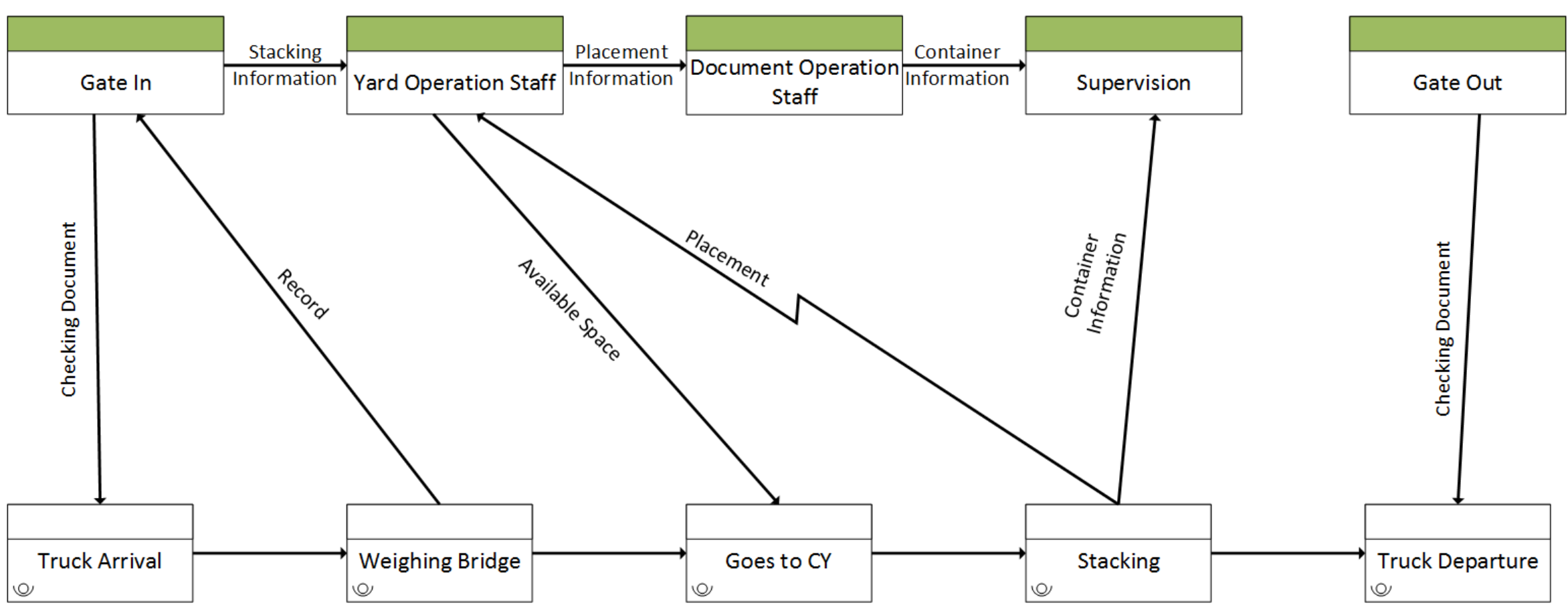


Lampiran 4. Current Value Stream Mapping Delievery Process

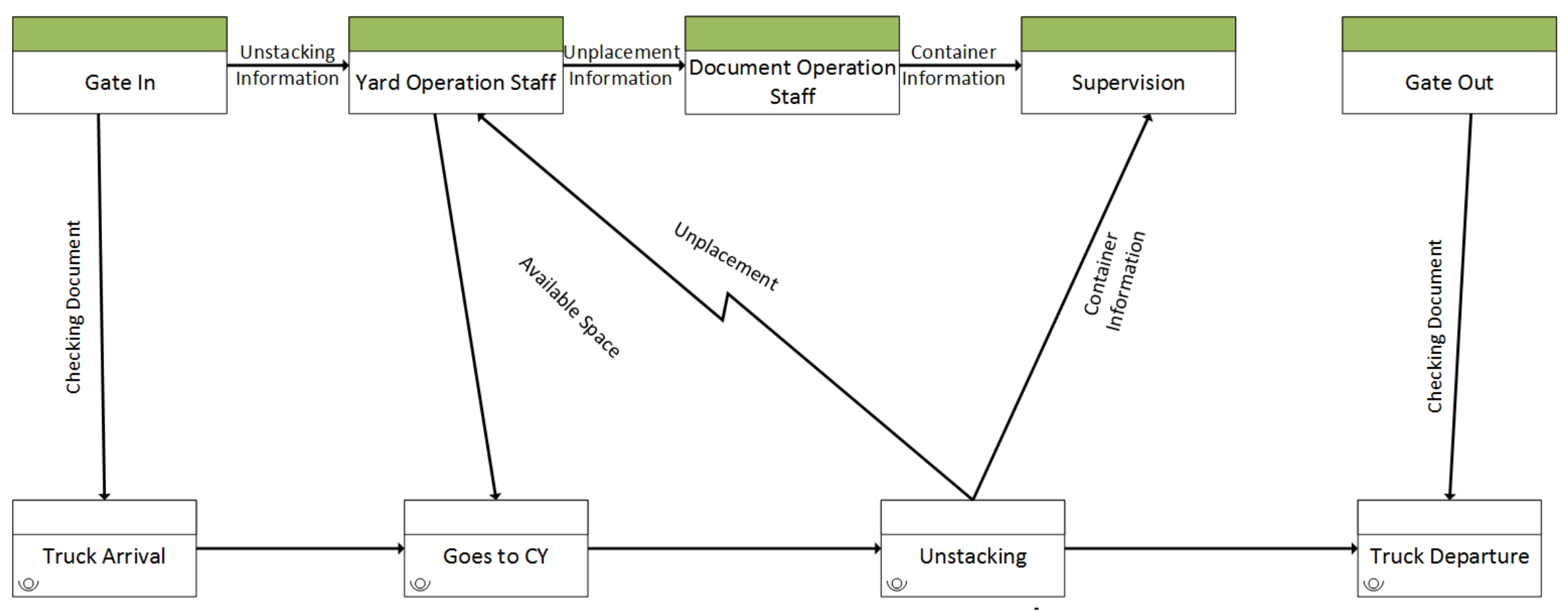

